EL DINAR: Jurnal Keuangan dan Perbankan Syariah

Volume 7 , No. 1, Tahun 2019

P ISSN: 2339-2797; E ISSN: 2622-0083

\title{
PRAKTIK MURABAHAH PADA KANINDO SYARIAH
}

\author{
Eka A. Shidarta, Yuli W. Astuti, Kholilah, dan Sheila F. Putri \\ Universitas Negeri Malang \\ eka.anantas@gmail.com
}

\section{Abstract}

Murabahah is $99.80 \%$ of the contracts used in financing distribution in Kanindo Sharia. This study aims to determine the problems faced by kanindo sharia in the implementation of the murabahah contract. This study uses phenomenology to answer the research objectives. Understanding of $A O$, guarantees, understanding of members, and accuracy of contracts used are four problems found in financing activities. The solutions used to solve these problems are training employees, rescheduling installments and withdrawing collateral, socializing and intensive approaches to members, as well as reviewing financing agreements. Accounting practices carried out by Kanindo Syariah are not in accordance with PSAK 102. Accounting recognition in accordance with PSAK 102 is only found in murabahah asset acquisition transactions.

Key words: Murabahah Contract, Murabahah Accounting, Penalty

\section{Abstrak}

Akad Murabahah merupakan 99,80\% akad yang digunakan dalam pembiayaan di Kanindo Syariah. Penelitian ini bertujuan untuk mengetahui permasalahan yang dihadapi kanindo syariah dalam implementasi akad murabahah. Penelitian ini menggunakan fenomenologi untuk menjawab tujuan penelitian. Pemahaman AO, jaminan, pemahaman anggota, dan ketepatan akad yang digunakan adalah empat masalah yang ditemukan dalam kegiatan pembiayaan. Solusi yang digunakan untuk menyelesaikan permasalahan tersebut adalah pelatihan kepada karyawan, penjadwalan ulang angsuran dan penarikan agunan, sosialisasi dan pendekatan intensif kepada anggota, serta peninjauan perjanjian pembiayaan. Praktik akuntansi yang dilakukan oleh Kanindo Syariah tidak sesuai dengan PSAK 102. Pengakuan akuntansi yang sesuai dengan PSAK 102 hanya terdapat pada transaksi perolehan aset murabahah.

Kata kunci: Akad Murabahah, Akuntansi Murabahah, Denda 
Eka A. Shidarta: Praktek Murabahah pada Kanido syariah

\section{PENDAHULUAN}

Baitul Maal wat Tamwil (BMT) adalah lembaga keuangan mikro yang memiliki prinsip bagi hasil dalam pengelolaan dananya. BMT memiliki beberapa peran penting yaitu motor penggerak kegiatan ekonomi kelas bawah, ujung tombak pelaksanaan prinsip-prinsip syariah, serta menjadi penghubung antara kaum kaya dengan kaum miskin (Hendro dan Cony, 2014; dan Yusuf, 2014). Penggerak kegiatan ekonomi kelas bawah dijabarkan oleh Lubis (2015) melalui pembinaan dan pendanaan usaha kecil sehingga mampu melepaskan masyarakat dari ketergantungan terhadap rentenir. Meskipun demikian, Agar dapat menjalankan perannya, BMT membutuhkan pendanaan yang cukup besar.

Pendanaan ini tidak hanya mengandalkan dari simpanan anggota, tetapi juga dari pihak ketiga. Salah satu faktor yang dapat meningkatkan jumlah pendanaan pihak ketiga pada sektor mikro adalah kualitas laporan keuangan (Niode et. al, 2016; Ayed \& Zouari, 2014; Abdulsaleh \& Wortington, 2013; Syariati, 2012). Rendahnya penerapan standar akuntansi keuangan (SAK) yang akan berpengaruh terhadap kualitas laporan keuangan akan mempengaruhi kepercayaan pihak ketiga terutama perbankan untuk memberikan pinjaman.

Pentingnya peran BMT tidak diimbangi dengan ketepatan pencatatan akuntansi atas akad-akad yang digunakan terutama pada kegiatan penyaluran dana (Hidayat, 2013; Ikhsan dan Haridhi, 2017). Sedangkan, pada akad penghimpunan dana berupa simpanan anggota telah dilakukan sesuai dengan standar akuntansi yang berlaku. Pengukuran simpanan anggota dilakukan dengan menambah jumlah setoran dan bagi hasil, yang dihitung berdasarkan jumlah rata-rata simpanan dan total rata-rata simpanan (Hizazi, Susfayetti, dan Rahayu; 2010).

Kanindo syariah adalah salah satu BMT di Jawa Timur yang memiliki misi untuk memajukan kegiatan ekonomi mikro, kecil, dan menengah. 99,80\% pembiayan yang disalurkan di Kanindo Syariah adalah pembiayaan murababah. Namun, pencatatan akuntansi murabahah belum dilakukan sesuai Pernyataan Standar Akuntansi Keuangan (PSAK) 102 tentang murabahah. 
Eka A. Shidarta: Praktek Murabahah pada Kanido syariah

Akuntansi murabahah termasuk salah satu akuntansi yang rumit karena terdapat beberapa pengakuan akun atas transaksi tersebut. Akuntansi murabahah melibatkan transaksi perolehan aset, akad, akhir periode pelaporan, pengakuan keuntungan, dan transaksi hutang piutang bermasalah. Implementasi PSAK 102 sukar sekali diterapkan oleh entitas syariah apalagi pada lembaga keuangan mikro syariah.

Perbedaan penelitian ini dengan penelitian yang lain adalah fokus penelitian pada praktik murabahah mulai proses bisnis sampai pencatatan akuntansi. Penelitian yang dilakukan oleh Hidayat (2013), Ikhsan dan Haridhi (2017) menyebutkan bahwa praktik akuntansi kegiatan penyaluran dana tidak dilakukan sesuai dengan PSAK. Oleh karena itu, penelitian ini bertujuan untuk mengetahui praktik pembiayaan murabahah serta pencatatan akuntansi di Kanindo Syariah.

\section{KAJIAN PUSTAKA \\ Perbankan Syariah}

Prinsip syariah yang dianut oleh lembaga keuangan Syariah (LKS) dilandasi oleh nilai-nilai keadilan, kemanfaatan, keseimbangan dan universalitas (rahmatan lil 'alamin). Ada 3 prinsip utama yang dianut oleh lembaga keuangan syariah dalam menjalankan kegiatan usahanya yaitu; bebas "Maghrib" (Maysir/ Spekulasi, Ghahar, Haram, Riba, dan Batil), menjalankan bisnis dengan aktivitas perdagangan yang berbasis pada perolehan keuntungan yang sah menurut syariah, dan terdapat kegiatan penyaluran zakat, infak, dan sedekah (Soemitra; 2009).

Struktur LKS di Indonesia terdiri dari (1) Perbankan Syariah (Bank Umum Syariah, Unit Usaha Syariah, dan Bank Pembiayaan Rakyat Syariah); (2) Lembaga Keuangan Syariah Non Bank (Pasar Modal, Perusahaan Asuransi, Dana Pensiun, Perusahaan Modal Ventura, Lembaga Pembiayaan yang terdiri dari Perusahaan Sewa Guna Usaha, Perusahaan Anjak Piutang, Perusahaan Pembiayaan Konsumen, dan Pegadaian); serta (3) Lembaga Keuangan Syariah Mikro (Lembaga Pengelola Zakat (BAZ dan LAZ), Lembaga Pengelola Wakaf, dan BMT (Soemitra; 2009).

Soemitra (2009) berpendapat bahwa keberadaan BMT memiliki dua fungsi utama yaitu, sebagai media penyalur pendayagunaan harta ibadah seperti zakat, infak, sedekah, dan wakaf, serta sebagai institusi 
Eka A. Shidarta: Praktek Murabahah pada Kanido syariah

yang bergerak di bidang investasi yang bersifat produktif (sebagai lembaga keuangan dan lembaga ekonomi) yang bertugas menghimpun dana dari masyarakat (anggota BMT) dan menyalurkan dana kepada masyarakat (anggota BMT) seperti mengelola kegiatan perdagangan, industri, dan pertanian.

\section{Akad Murabahah}

Murabahah adalah bagian dari jenis bai' yaitu jual beli yang ditambah dengan sejumlah keuntungan yang disepakati oleh penjual dan pembeli. Pada transaksi murabahah penyerahan barang akan dilakukan saat pembayaran transaksi dilaksanakan oleh pembeli baik secara tunai, ditangguhkan, maupun dengan cara cicilan (Wasilah, 2015; Hendro dan Conny, 2014; Soemitra, 2009). Menurut PSAK 102, murabahah dapat dilakukan berdasarkan pesanan atau tanpa pesanan.

Pada murabahah berdasarkan pesanan, penjual melakukan pembelian barang setelah ada pemesanan dari pembeli. Murabahah berdasarkan pesanan dapat bersifat mengikat atau tidak mengikat pembeli untuk membeli barang yang dipesannya. Alqur'an surat Albaqarah ayat 275 menjadi dasar hukum pelaksanaan akad murabahah. Ayat tersebut berbunyi; "Allah menghalalkan jual beli dan mengharamkan riba".

\section{Akuntansi untuk Penjual Aset Murabahah}

Akuntansi untuk aset murababah meliputi kegiatan pengakuan, pengukuran, penyajian, dan pengungkapan. Kegiatan pengakuan melibatkan empat aktivitas yaitu perolehan aset murabahah, akad, pembayaran angsuran dan restrukturisasi piutang bermasalah. Pada saat perolehan aset murabahah, penjual mengakui aset tersebut sebagai persediaan sebesar biaya perolehan (Wasilah dan Nurhayati, 2015). Pada saat akad, piutang diakui sebesar biaya perolehan ditambah dengan margin (Wasilah dan Nur Hayati, 2015).

Pada akhir periode pelaporan keuangan, piutang murabahah dinilai sebesar nilai realisasi bersih, yaitu saldo piutang murabahah dikurangi penyisihan kerugian piutang. Pengakuan atas penyisihan piutang sama dengan pengakuan pada akuntansi konvensional. Pada saat pembayaran angsuran, penjual sudah bisa merealisasikan 
Eka A. Shidarta: Praktek Murabahah pada Kanido syariah

keuntungan sebagai pengurang margin murabahah tangguhan (Wasilah dan Nurhayati, 2015). Pada saat pembeli lalai dalam melaksanakan kewajibannya, penjual dapat memberikan sangsi kepada pembeli (Fatwa DSN Nomor: 17/DSN-MUI/IX/2000), dengan mengakui transaksi tersebut sebagai dana kebajikan.

Denda tidak boleh diakui sebagai pendapatan oleh entitas, namun dikumpulkan dalam akun tampungan yang bisa diberikan kepada pihak lain dalam bentuk pembiayaan qordhul hasan atau kegiatan kebajikan yang lain (Fatwa DSN Nomor: 17/DSN-MUI/IX/2000). Restrukturisasi piutang murabahah bermasalah. Penyelesaian atas piutang murabahah yang bermasalah bisa dilakukan dalam setidaknya tiga langkah (Wasilah dan Nurhayati, 2015) yaitu; pemberian potongan tagihan, penjadwalan kembali, dan konversi akad.

Piutang murabahah disajikan sebesar nilai bersih yang dapat direalisasikan, yaitu saldo piutang murabahah dikurangi penyisihan kerugian piutang. Margin murabahah tangguhan disajikan sebagai pengurang (contra account) piutang murabahah. Apabila penjual menggunakan metode anuitas untuk akad murabahah, maka piutang murabahah akan disajikan sebesar biaya perolehan yang diamortisasi dengan menggunakan effective rate. Apabila terjadi penurunan nilai karena pembeli tidak mampu melaksanakan kewajibannya maka penurunan nilai akan disajikan sebagai kontra akun terhadap piutang sesuai PSAK 55. Penjual mengungkapkan hal-hal yang terkait dengan transaksi murabahah, bukan hanya atas harga perolehan aset murabahah, janji pemesanan dalam murabahah berdasarkan pesanan sebagai kewajiban atau bukan, Pengungkapan yang diperlukan sesuai PSAK 101 tentang Penyajian Laporan Keuangan Syariah.

\section{METODE}

Penelitian ini berusaha untuk menganalisis fenomena, peristiwa, aktivitas sosial, persepsi, serta sikap orang secara individual maupun kelompok atas praktik pembiayaan dan akuntansi murabahah di Kanindo Syariah. Oleh karena itu, peneliti menggunakan pendekatan penelitian kualitatif dengan metode fenomenologi. Peneliti memandang bahwa praktik penyusanan laporan keuangan adalah sebuah fenomena, 
Eka A. Shidarta: Praktek Murabahah pada Kanido syariah

sehingga untuk memahami fenomena, peneliti mengesampingkan pengetahuan dan pemahaman yang dimiliki oleh peneliti.

Proses ini dilakukan untuk mendapatkan informasi yang baru, orisinil, dan jauh dari bias argumentasi peneliti. Pada proses ini, peneliti memasuki dunia pemahaman informan, sehingga konsep yang ditangkap peneliti utuh memotret praktik pengukuran, pengakuan, penyajian, dan pengungkapan akuntansi atas transaksi pembiayaan murabahah. Informan utama sekaligus objek utama dalam penelitian ini adalah manajer operasional, manajer keuangan, kepala cabang, account officer (A0), bagian keuangan, dan kasir di Kanindo Syariah. Kriteria penentuannya adalah peran dan hubungan informan dengan pembiayaan murabahah.

\section{Sumber Data}

Serangkaian langkah yang dilakukan dalam proses pengumpulan data untuk penelitian ini adalah observasi, wawancara mendalam, analisis data sekunder, dan Focus Group Discussion (FGD). Observasi dilakukan dengan melihat proses pencatatan atas transaksi penerimaan angsuran dan akad pembiayaan murabahah. Peneliti menggunakan wawancara mendalam untuk mengumpulkan sebanyak mungkin informasi dari para informan. Pedoman wawancara dibuat hanya untuk memberikan batasan minimal informasi yang harus didapatkan. Semakin beragam jawaban para informan, semakin banyak informasi yang didapatkan atas praktik akuntansi pembiayaan murabahah. Informasi tersebut akan dikategorisasi dan ditanyakan ulang dengan bahasa yang berbeda hingga mencapai titik jenuh (saturation). Titik jenuh adalah titik tidak adanya informasi baru lagi untuk menggambarkan fenomena yang diteliti (Bungin, 2012).

Analisis data sekunder dilakukan dengan melihat dan mengumpulkan data - data terkait penyusunan laporan keuangan, bukti transaksi, ayat jurnal, kartu pembayaran angsuran, dokumen akad perikatan pembiayaan murabahah, berita, dan artikel terkait lain agar dapat memberikan gambaran bahasan yang utuh atas fenomena penelitian. FGD merupakan teknik validitas data yang dilakukan peneliti untuk memastikan konsistensi jawaban informan dalam wawancara mendalam. Teknik pelaksanaanya adalah dengan mengundang para 
Eka A. Shidarta: Praktek Murabahah pada Kanido syariah

informan dalam suatu pertemuan untuk membahas praktik pembiayaan murabahah. Kegiatan ini dihadiri oleh 65 orang peserta yang dibagi dalam empat kelompok. Masing-masing kelompok didampingi oleh satu peneliti untuk mengetahui variansi pemahaman informan atas praktik dan akuntansi pembiayaan murabahah.

\section{Teknik Analisis Data}

Logika berpikir dalam penelitian kualitatif adalah induktif abstraktif (Bungin, 2012). Sehingga teknik analisis data tidak harus dilakukan secara kaku dan terstruktur seperti dalam penelitian kuantitatif. Oleh karena itu, setiap tahapan dalam penelitian didesain sedemikian rupa untuk mendapatkan informasi yang relevan dan reliable. Teknik analisis data yang dilakukan dalam penelitian ini adalah reduksi data, penyajian data, dan penarikan kesimpulan. Data yang diperoleh dipilah berdasarkan hubungannya dengan pemahaman informan atas praktik pembiayaan murabahah.

Proses penyajian data adalah proses organisasi data menjadi matriks, sinopsis atau bentuk-bentuk lain untuk memudahkan pemaparan dan penegasan kesimpulan (Bungin, 2012). Data yang diperoleh dipilih berdasarkan kategori tertentu seperti yang dibahas dalam reduksi data. Kategori atau intensitas munculnya kata dikumpulkan dalam satu kategori sehingga menghasilkan kata-kata kunci dalam penelitian. Ketepatan dalam proses penyajian data mempermudah proses penarikan kesimpulan. Pada tahap ini, kata-kata kunci dari informan diintrerpretasikan sesuai dengan teori yang ada untuk memahami praktik dan akuntansi pembiayaan murabahah.

\section{PEMBAHASAN}

\section{Gambaran Umum Kanindo Syariah}

Kanindo adalah salah satu koperasi yang didirikan pada tahun 1998 oleh beberapa aktifis gerakan koperasi, Lembaga Swadaya Masyarakat (LSM), dan tokoh masyarakat. Kanindo didirikan dalam rangka menggalang kekuatan kolektif masyarakat dari berbagai kalangan, mulai dari petani, peternak, pedagang, industri kecil, pengrajin dan wirausahawan lainya untuk mendukung gerakan ekonomi rakyat. Pada awal berdirinya, Kanindo menggunakan sistem ekonomi 
Eka A. Shidarta: Praktek Murabahah pada Kanido syariah

konvensional yang berbasis bunga dalam ativitas operasionalnya. Pada tahun 2003 Kanindo mengganti sistem pencatatan dan operasionalnya dengan sistem ekonomi syariah, sekaligus mengganti nama koperasi menjadi Kanindo Syariah.

Kanindo syariah memiliki dua unit usaha yaitu unit jasa keuangan dan unit perumahan. Unit jasa keuangan memiliki dua jenis pelayanan meliputi pengumpulan dana (funding) dan penyaluran pembiayaan (lending). Kegiatan unit jasa keuangan dibantu oleh dua divisi yaitu Account Officer (AO) dan Customer Service (CS). Dua divisi tersebut memiliki fungsi dan peran yang berbeda. AO memiliki tugas utama untuk menangani masalah lapangan yaitu analisis kelayakan pembiayaan bagi anggota melalui pedoman 5 C yang dikembangkan oleh Kasmir (2014) yaitu Character, Capacity, Capital, Collateral, dan Condition. Tidak ada pemisahan fungsi funding dan lending bagi setiap AO, sehingga AO memiliki baik target funding ataupun lending setiap tahun. CS dibedakan menjadi dua bagian yaitu teller dan pembukuan. Teller berfungsi sebagai kasir yaitu menerima dana dari anggota melalui penerimaan simpanan dan pembayaran angsuran, serta penyaluran dana pembiayaan. Pencatatan akuntansi dilakukan oleh bagian pembukuan.

\section{Kegiatan Pembiayaan di Kanindo Syariah}

Lending dibedakan menjadi dua kategori pembiayaan yaitu produksi dan konsumsi. Skema yang digunakan dalam dua kegiatan tersebut adalah Murabahah, Mudharabah, Musyarakah, Bai' Bitsaman Ajil, dan Qordul Hasan. Meskipun demikian, berdadasarkan wawancara yang dilakukan dengan AO dan kepala cabang pembantu, akad murabahah adalah akad yang paling dominan di Kanindo Syariah dengan presentase sebesar 99,80\%. Alasan pemilihan akad ini dikemukakan oleh M. Taufiqurrohman selaku kepala cabang pembantu Kepanjen sebagai berikut.

"Akad murabahah itu paling gampang mbak, gak ribet, jelasin ke anggota mudah, dan perhitungannya juga jelas, kayak kita jualan biasa mbak. Harga kulakannya jelas, kita ngambil keuntungan juga jelas".

Alasan ini juga diperkuat oleh Yoserizal yang menjelaskan bahwa perhitungan matematis akad murabahah juga bisa lebih mudah 
Eka A. Shidarta: Praktek Murabahah pada Kanido syariah

dijelaskan kepada nasabah. Berikut adalah hasil wawancara yang dilakukan dengan Yoserizal.

"Sama seperti ini mbak, ketika ada seseorang yang punya hajat, beliau ingin membeli kambing dengan kisaran harga maksimal $R p$ 1.000.000. Kemudian kami mencarikan kambing tersebut dengan harga yang dikehendaki oleh sang pemilik hajat. Setelah itu, kami komunikasikan misalnya kami akan mengambil keuntungan sebesar Rp 200.000, nah cicilannya akan diselesaikan selama 10 bulan, jadi setiap bulannya beliau akan membayar keuntungan kepada kami Rp 20.000 dan cicilan sebesar Rp 100.000. Apabila dalam jangka waktu 1 bulan setelah akad ternyata yang punya hajat tadi sudah memiliki uang untuk melunasi hutangnya. Ya sudah yang beliau bayarkan hanya $\mathrm{Rp} 1.020 .000$ jadi kami hanya mengambil keuntungan sebesar Rp. 20.000 dalam jangka waktu 1 bulan".

Berbeda dengan lembaga keuangan mikro yang lain, dalam praktiknya Kanindo Syariah tidak hanya mengutamakan kegiatan usahanya. Kegiatan pembinaan dan pendekatan kepada anggota juga menjadi prioritas dalam operasional Kanindo Syariah. Hal ini dilakukan karena mayoritas anggota kanindo syariah adalah penduduk desa yang membutuhkan pendekatan kekeluargaan dalam membangun hubungan. Hal ini diungkapkan oleh salah satu AO yang tidak bersedia menyebutkan namanya sebagai berikut.

"Kalau menjelaskan apa-apa harus dengan bahasa yang sederhana mbak, bahasa yang biasa mereka pakai, makanya kami tidak pernah menggunakan istilah margin atau bagi hasil, kami bilang saja, keuntungan".

Proses ini memudahkan komunikasi yang dilakukan oleh AO kepada anggota ataupun calon anggota. Penilaian kelayakan pemberian pinjaman menggunakan teknik 5C untuk mengurangi risiko kredit macet oleh kreditor. Selain itu, terdapat serangkaian prosedur dan langkahlangkah yang harus dilakukan oleh anggota ketika mengajukan pembiayaan seperti yang digambarkan dalam alur berikut; 
Eka A. Shidarta: Praktek Murabahah pada Kanido syariah

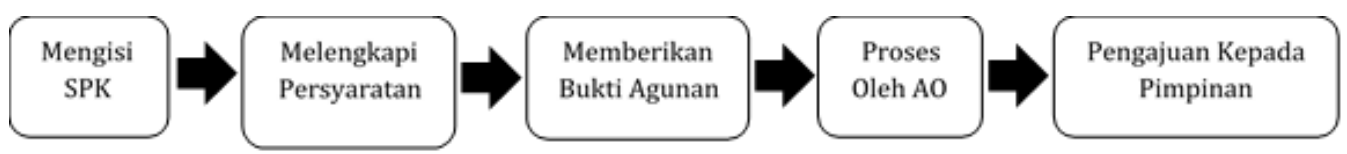

Gambar 1. Alur Pembiayaan

Sumber: Data Diolah, 2018

Keterangan:

SPK: Surat Permohonan Kredit

Persyaratan pembiayaan sama seperti pada lembaga keuangan konvensional yaitu Focotopy Kartu Tanda Kependudukan (KTP), surat nikah, slip gaji/surat keterangan penghasilan, dan data pendukung lainnya. Analisa lebih lanjut dilakukan oleh AO untuk melihat kemampuan anggota dalam melaksanakan kewajibannya. Proses ini dilakukan dengan cara silaturrahim langsung kepada anggota, sehingga AO bisa menilai kelayakan usaha dari wawancara dan pengamatan langsung kepada anggota.

\section{Permasalahan dalam Pembiayaan Murabahah}

Berdasarkan hasil FGD terdapat beberapa permasalahan yang dialami oleh Kanindo dalam praktik pembiayan murabahah yaitu; 1) pemahaman A0, 2) agunan, 3) pemahaman anggota terhadap akad, dan 4) ketepatan akad. Berikut adalah pemaparan atas keempat masalah utama tersebut. Pertama, Pemahaman yang tidak merata antar AO menyebabkabkan perbedaan operasional antara kantor pusat dengan kantor cabang, dan sesama kantor cabang. Hal ini dikemukakan oleh Aspari salah satu AO yang paling senior di Kanindo Syariah.

"Banyak AO baru mbak, mereka biasanya kurang begitu paham operasional, akad, dan ketentuan lainnya. Dengan pemahaman seperti itu, mereka sudah memiliki target pembiayaan dan penyaluran dana. Sehingga, ketika menjelaskan ke anggota juga ala kadarnya yang penting nyampe target".

Kedua, agunan merupakan salah satu permasalahan utama dalam eksekusi pembiayaan murabahah bermasalah. Permasalahan yang dialami oleh Kanindo terkait dengan agunannya adalah nilai jaminan 
Eka A. Shidarta: Praktek Murabahah pada Kanido syariah

yang melebihi jumlah pembiayaan dan bentuk agunan. Agunan merupakan aset yang dijaminkan oleh anggota dalam pembiayaan, Nilai agunan yang lebih tinggi dari pada nilai pinjaman menyebabkan AO dan manajemen Kanindo kesulitan dalam melakukan proses eksekusi atas pembiayaan bermasalah. Agunan berbentuk barang bergerak memiliki potensi besar untuk berpindah tangan selama proses pembiayaan, sehingga mempersulit proses eksekusi agunan.Seperti yang diungkapkan oleh Hadi Priyanto.

"Kadang gini mbak, pinjam $R p$ 5.000.000, jaminannya mobil. Kalau gak mampu bayar, masak ia kami ambil mobilnya? Kan jauh dari nilai pinjamannya mbak. Secara syariah kami juga tidak tahu bagaimana memperlakukannya".

Ketiga, permasalahan yang terjadi pada hampir semua lembaga keuangan syariah adalah pemahaman masyarakat terhadap akad murabahah yang digunakan dalam kegiatan operasional. Hal ini juga terjadi di Kanindo Syariah. Sebagian besar nasabah beranggapan bahwa label syariah yang digunakan oleh Kanindo Syariah berarti jumlah pembayaran pinjaman sebesar nilai pokoknya saja, sehingga pada saat pelunasan sebagian besar nasabah keberatan dengan jumlah margin yang harus dibayar. Permasalahan ini juga muncul karena bentuk buku pembayaran angsuran memisahkan antara jumlah pokok dengan jumlah margin. Hal ini diungkapkan oleh Wahib.

"Bentuk buku pembayaran angsurannya lho Pak, bikin bingung anggota. Mereka sering berpikir bahwa ketika mengangsur ya sudah senilai pinjamannya saja. Padahal kalau bilang murabahah kan harus jual beli bukan pinjaman".

Permasalahan lain yang dihadapi oleh Kanindo terkait pemahaman masyarakat adalah penggunaan akad wakalah. Akad ini memberikan wewenang kepada pihak lain untuk mewakili peminjam dalam proses pembiayaan. Pada praktiknya saat pembiayaan tersebut bermasalah maka kedua belah pihak saling melemparkan tanggung jawab untuk menghindari kewajiban angsuran. Hal ini disebutkan oleh Yoserizal.

"ya gitu mas, kalau udah waktunya bayar angsuran bingung, nagih ke yang pinjam, katanya namanya aja yang dipakai. Nagih 
Eka A. Shidarta: Praktek Murabahah pada Kanido syariah

ke orang yang mewakili, katanya dia hanya bantu mempercepat proses".

Keempat, presentase pembiayaan murabahah sebesar 99,80\% dari total penyaluran dana tidak berarti bahwa akad ini mampu mewakili seluruh kegiatan bisnis Kanindo Syariah. Pada praktiknya banyak kegiatan yang tidak memenuhi kriteria murabahah. Contoh yang paling banyak dilakukan adalah pembiayaan untuk biaya pendidikan dan kesehatan. Hal ini diungkapkan oleh Farid Kurniawan.

"Murabahah kan jual beli ya mbak, kebanyakan anggota pinjam untuk membayar sekolah dan biaya rumah sakit. Kalau seperti itu apanya yang diperjual belikan mbak?".

Pendekatan secara kekeluargaan biasanya dipilih oleh Kanindo Syariah untuk menyelesaikan permasalahan dari kegiatan murabahah, berikut adalah langkah-langkah yang dilakukan Kanindo Syariah untuk menyelesaikan masalah tersebut. Pertama, pelatihan yang berkelanjutan kepada AO tentang praktik-praktik terbaru di dunia perbankan, akuntansi, dan manajerial. Pelatihan ini diselenggarakan atas kerja sama dengan perbankan syariah, perguruan tinggi, dan lembaga-lembaga yang lain. Pelatihan dilakukan secara berkala dengan mempertimbangkan tingkat urgensi topik.

Kedua, penarikan jaminan dilakukan ketika nasabah melakukan wanprestasi dan tidak memiliki iktikad baik untuk melunasi hutangnya. Kanindo Syariah akan mengembalikan sisa penjualan jaminan apabila nilainya melebihi sisa angsuran. Dalam kondisi anggota tidak melakukan wanprestasi maka Kanindo Syariah akan melakukan pembinaan secara intensif dan perpanjangan waktu pembayaran bagi anggota yang memiliki permasalahan pembayaran angsuran.

Pembinaan dilakukan dengan cara silaturahim ke anggota dan memberikan solusi yang mungkin dapat diterapkan untuk mengatasi kesulitan pembayaran yang dialami anggota. Perpanjangan waktu (rescheduling), tahap ini dilakukan apabila hasil survey kepada anggota, AO menyimpulkan bahwa anggota masih mampu melunasi pinjaman. Koreksi oleh kantor pusat dilakukan untuk melihat ketepatan penerapan perpanjangan waktu oleh anggota.

Ketiga, sosialisasi secara intensif oleh AO kepada setiap anggota tentang akad murabahah. Hal ini dilakukan karena nasabah sering rancu antara akad murabahah dan mudharabah, serta konsekuensi EL DINAR Volume 7, No.1, Tahun 2019 | 27 
Eka A. Shidarta: Praktek Murabahah pada Kanido syariah

penggunaan akad dalam pembiayaan. Keempat, pengkajian ulang terhadap akad - akad pembiayaan lain yang lebih sesuai dengan kegiatan bisnis Kanindo Syariah. Ketepatan dalam penggunaan akad, akan mempermudah AO dalam menjelaskan kepada anggota tentang pembiayaan yang dibutuhkan.

\section{Praktik Akuntansi Murabahah}

Kegiatan pengakuan melibatkan empat aktivitas yaitu perolehan aset murabahah, akad, pembayaran angsuran dan restrukturisasi piutang bermasalah. Atas keempat aktivitas tersebut, pengakuan aset murabahah adalah satu-satunya pencatatan yang sesuai dengan PSAK 102, sedangkan tiga kegiatan yang lain belum dilakukan sesuai dengan standar yang berlaku. Pada saat perolehan aset murabahah, Kanindo Syariah mengakui aset tersebut sebagai persediaan sebesar biaya perolehan dari supplier.

Pada saat akad, piutang diakui sebesar biaya perolehan. Hal ini menyebabkan anggota kesulitan untuk mengakui margin dalam pembayaran angsuran, yang berdampak terhadap pembiayaan murabahah pemahaman anggota. Pada saat pembayaran angsuran, keuntungan atas penjualan aset murabahah baru diakui sebagai margin murabahah. Sehingga, tidak ada pengakuan margin murabahah tangguhan atas transaksi murabahah. Prinsip ini menunjukkan bahwa dalam pengakuan pendapatan, Kanindo Syariah masih menggunakan metode cash basis. Pengakuan ini juga menyebabkan tidak adanya pengakuan penurunan nilai atas penjualan aset murabahah.

Penyelesaian atas piutang murabahah bermasalah dilakukan dengan penjadwalan kembali. Kanindo syariah memiliki batasan kriteria tidak mampu membayar angsuran terhadap anggotanya. Batasan kriteria ini adalah ketepatan waktu dalam pembayaran angsuran. Pada umumnya lembaga keuangan lain akan memberikan denda kepada nasabah yang terlambat melakukan pembayaran. Di Kanindo Syariah, keterlambatan pembayaran angsuran hanya diberikan himbauan untuk mengisi kotak infaq sesuai dengan kesadaran anggota dengan jumlah yang tidak ditentukan. Langkah tersebut dilakukan setelah AO memberikan perpanjangan waktu pembayaran, namun angggota tetap tidak mampu melakukan pembayaran. Pengenaan denda yang bersifat 
Eka A. Shidarta: Praktek Murabahah pada Kanido syariah

sukarela dengan besaran yang tidak ditentukan menyebabkan tidak ada pembukuan yang dilakukan oleh entitas atas pengenaan denda.

Penyaluran pembiayaan di Kanindo Syariah tidak menggunakan akta notaris. Sehingga memudahkan Kanindo Syariah untuk mengubah jadwal dan besaran angsuran. Perubahan ini dilakukan dengan cara musyawarah dengan anggota yang bersangkutan sesuai dengan kondisi keuangan anggota. Kanindo Syariah tidak membiarkan pembiayaan macet terjadi. Kanindo Syariah akan mengusahakan berbagai cara ketika anggota tidak membayar angsurannya. Pada beberapa kasus, AO menggunakan media sosial facebook untuk menagih angsuran apabila anggota tidak bisa dihubungi melalui telepone, dan tidak bisa ditemui di rumah atau tempat kerja. Kondisi ini menjadi rasionalisasi atas tidak adanya pengakuan penyisihan piutang tak tertagih.

\section{KESIMPULAN}

Berdasarkan hasil penelitian dan pembahasan yang dijelaskan, maka dapat diambil kesimpulan sebagai berikut: akad murabahah adalah akad yang paling banyak digunakan dalam penyaluran pembiayaan di Kanindo Syariah. Terdapat empat permasalahan utama dalam pembiayaan ini yaitu; pemahaman AO, jaminan, pemahaman anggota, dan ketepatan akad. Solusi yang dilakukan untuk mengatasi masalah tersebut adalah pelatihan berkelanjutan kepada karyawan, penjadwalan kembali dan penarikan jaminan, sosialisasi dan pendekatan intensif kepada anggota, serta pengkajian ulang terhadap akad pembiayaan.

Praktik akuntansi yang dilakukan oleh Kanindo Syariah belum sesuai dengan PSAK 102. Dari empat pengakuan utama atas transaksi murabahah yaitu periode perolehan aset, akad, pembayaran angsuran, dan rekstrukturisasi piutang bermasalah. Pencatatan akuntansi yang tepat hanya pengakuan perolehan aset murabahah.

Denda dilakukan kepada anggota untuk memberikan efek jera atas keterlambatan pembayaran. Tidak ada ketentuan atas besaran jumlah denda. Anggota mengeluarkan denda di kotak infaq yang telah disediakan. Kanindo syariah tidak melakukan pencatatan atas pendapatan denda. Denda yang terakumulasi akan disalurkan kepada pihak-pihak yang membutuhkan melalui akad qordul hasan. 
Eka A. Shidarta: Praktek Murabahah pada Kanido syariah DAFTAR PUSTAKA

Abdulsaleh, A.M., \& Worthington, A.C. 2013. Small and Medium-Sized Enterprises Financing: A Review og the Literature. International journal of Business and Management, 8(4): 36-54

Ayed, Wafa Hadriche Ben, dan Sonia Ghorbel Zouri. 2014. Capital Structure and Financing of SMEs: The Tunisian Case. International Journal of Economics and Finance; Vol. 6, No. 5, 2014

Bungin, Burhan. 2012. Analisis Data Penelitian Kualitatif. Jakarta: Rajawali Press

Fatwa DSN Nomor:17/DSN-MUI/XI/2000

Hendro, Tri dan Cony Tjandra Raharja. 2014. Bank dan Institusi Keuangan Non Bank di Indonesia. Yogyakarta: UPP STIM YKPN

Hidayat, Solikhul. 2013. Penerapan Akuntansi Syariah pada BMT Lisa Sejahtera Jepara. Jurnal Dinamika Ekonomi dan Bisnis Vol. 10 No. 2 Oktober 2013.

Hizazi, Achmad, Susfayetti dan Sri Rahayu. 2010. Analisis Penerapan Akuntansi Syariah di BMT Al Ishlah Kota Jambi. Jurnal Penelitian Universitas Jambi Seri Humaniora Volume 12, Nomor 2, Hal. 47-56 Juli - Desember 2010.

Ikhsan, Amrul dan Musfiari Haridhi. 2017. Penerapan Standar Akuntansi Keuangan Syariah pada Koperasi Jasa Keuangan Syariah (Studi Pada Baitul Qiradh Di Kota Banda Aceh). Jurnal Ilmiah Mahasiswa Ekonomi Akuntansi (JIMEKA) Vol. 2, No. 3, (2017) Halaman 100-110.

Lubis, Rini Hayati. 2015. Peranan Baitul Mal Wat Tamwil terhadap Perekonomian Sumatera Utara. AL-MASHARIF Volume 3, No. 2, Juli-Desember 2015.

Kasmir. 2014. Analisis Laporan Keuangan, Edisi Satu Cetakan Ketujuh. Jakarta: PT. Raja Grafindo Persada

Niode, Marshella Patricia, David Paul Elia Saerang, Ventje Ilat. 2016. Analisis Penggunaan Informasi Akuntansi dan Informasi Non Akuntansi dalam Keputusan Pemberian Fasilitas Kredit pada PT. Bank Mandiri (Persero) Tbk. Area Manado. Accountability Vol. 5 No. 2 Desember 2016

Soemitra, A. 2009. Bank dan Lembaga Keuangan Syariah: Deskripsi dan Ilustrasi. Jakarta: Kencana. 
Eka A. Shidarta: Praktek Murabahah pada Kanido syariah

Syariati, Dian. 2012. Memahami Praktik Akuntansi Perusahaan Manufaktur Skala Mikro. Tesis. Malang: Program Magister Akuntansi Pascasarjana Fakultas Ekonomi dan Bisnis Universitas Brawijaya.

Wasilah dan Sri Nurhayati. 2015. Akuntansi Syariah di Indonesia. Jakarta: Salemba Empat. 